\title{
P. falciparum
}
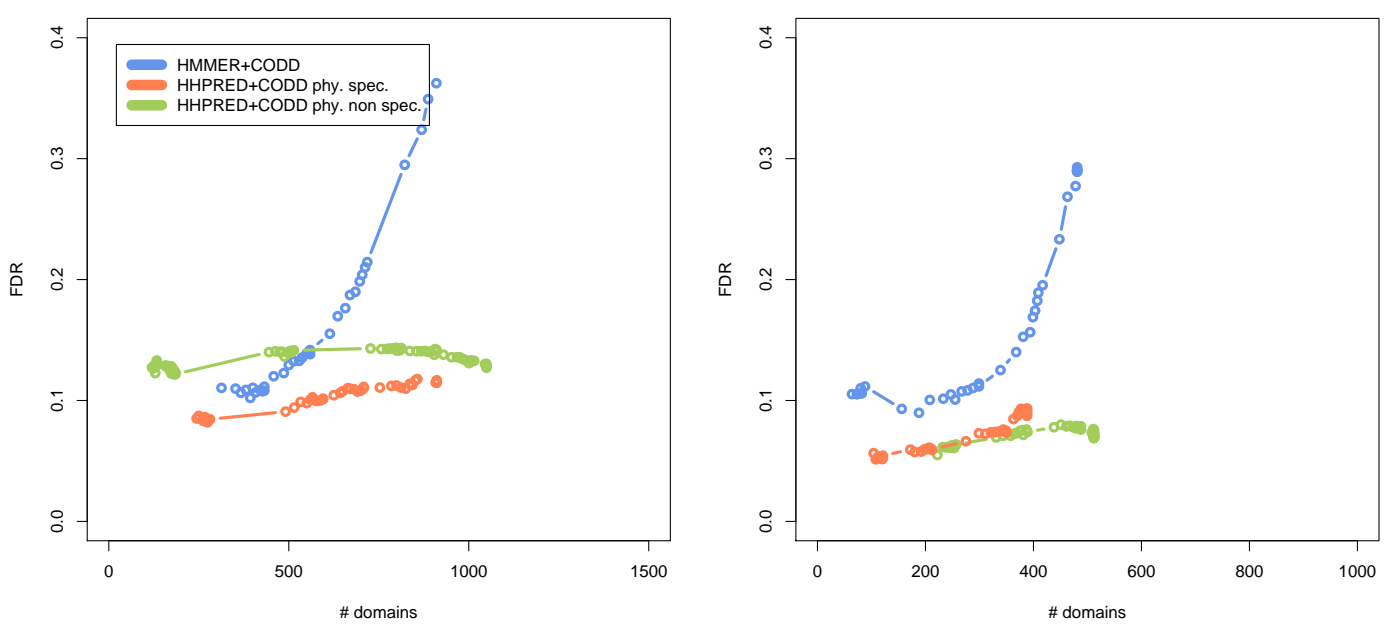

\section{L. major}
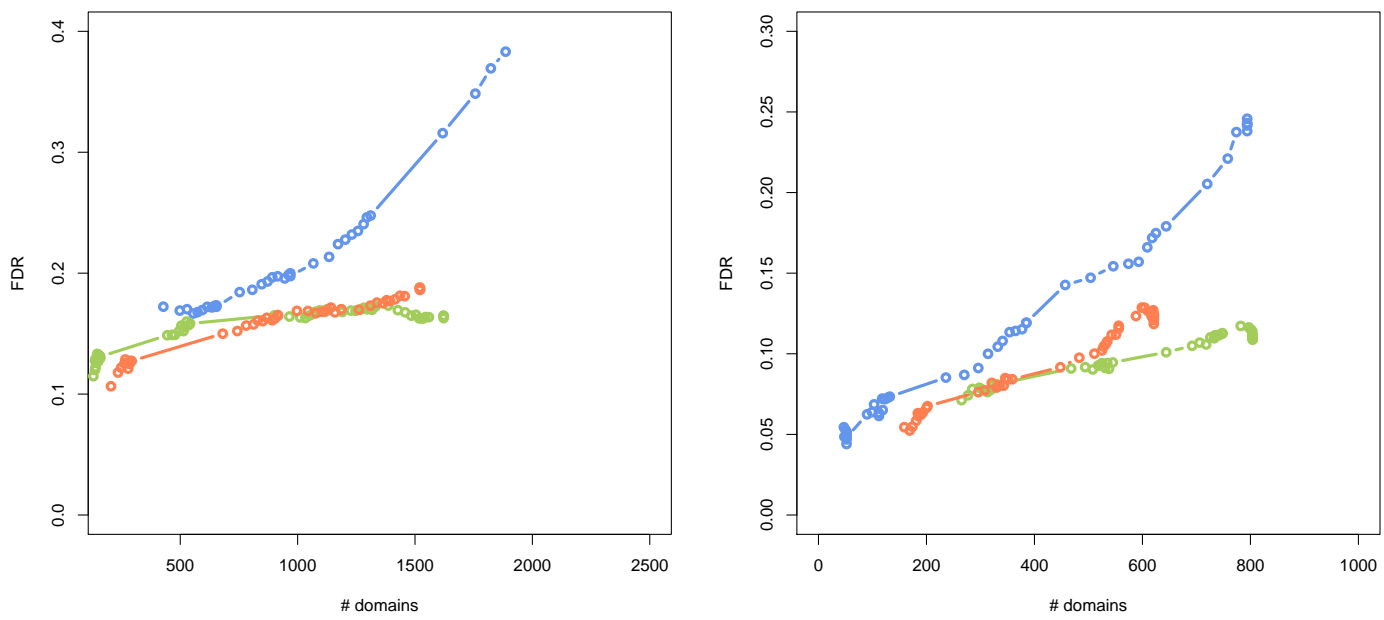